\title{
RESPONS TERHADAP KETIDAKSANTUNAN DALAM FILM THE RAID DAN THE RAID 2: BERANDAL KARYA GARETH EVANS
}

\author{
Jemima Jannah Darla Putri \\ Universitas Sebelas Maret \\ jemimajdarlaputri@student.uns.ac.id
}

\begin{abstract}
Abstrak
Fenomena ketidaksantunan menjadi hal yang lumrah di masyarakat. Tidak hanya dalam kehidupan sehari-hari, ketidaksantunan juga ditemukan dalam film. Tuturan tidak santun memiliki strategi yang diterapkan oleh penutur yakni strategi ketidaksantunan. Selain itu, terdapat pula respons terhadap ketidaksantunan yang diberikan oleh mitra tutur ketika merasakan serangan muka dari penutur. Artikel ini bertujuan untuk mendeskripsikan respons terhadap ketidaksantunan yang digunakan oleh tokoh-tokoh dalam film The Raid dan The Raid 2: Berandal karya Gareth Evans. Penelitian ini merupakan penelitian kualitatif deskriptif. Data dalam penelitian ini berupa tuturan yang mengandung respons terhadap ketidaksantunan dalam film The Raid dan The Raid 2: Berandal. Metode pengumpulan data yang dilakukan dalam penelitian ini adalah metode simak dengan teknik unduh dan teknik catat. Metode analisis data yang digunakan adalah metode analisis kontekstual. Analisis dalam penelitan ini didasarkan pada teori ketidaksantunan Jonathan Culpeper. Hasil penelitian menunjukkan bahwa respons terhadap ketidaksantunan yang ditemukan meliputi empat respons, yaitu strategi ofensif-ofensif sebanyak 11 data tuturan, strategi ofensif-defensif sebanyak 28 data tuturan, menerima sebanyak 3 data tuturan, dan tidak merespons sebanyak 12 data tuturan.
\end{abstract}

Kata-kata kunci: ketidaksantunan, respons, film

\begin{abstract}
The phenomenon of impoliteness is commonplace in society. Not only in daily life, impoliteness is also found in the movies. When speaking not polite, there is a strategy applied by speaker, namely the strategy of impoliteness. In addition, there are also responses to impoliteness given by the hearer when they feel the face-threatening act from the speaker. This article aims to describe the responses to impoliteness used by the characters in The Raid and The Raid 2: Berandal movies by Gareth Evans. The type of this research is descriptive qualitative research. The data in this research form of speech that contains responses to impoliteness in The Raid and The Raid 2: Berandal movies. The data-supplying method in this research was referring method with download techniques and note-taking techniques. The data analysis method used is contextual analysis method. The analysis in this research is based on Jonathan Culpeper's impoliteness theory. The results showed that the responses to impoliteness found include four responses, namely offensiveoffensive strategy as much as 11 speech data, offensive-defensive strategy as much as 28 speech data, accept as much as 3 speech data, and do not respond as much as 12 speech data.
\end{abstract}

Keywords: impoliteness, responses, film

\section{PENDAHULUAN}

Kesantunan merupakan aspek yang sangat penting dalam komunikasi. Akhir-akhir ini, bertutur dengan tidak santun bukan lagi hal yang "aneh" di masyarakat. Fenomena ini seakan telah menjadi kebiasaan yang lumrah di masyarakat Indonesia, terutama di kalangan anak muda. Ketidaksantunan tidak 
hanya ditemukan dalam kehidupan sehari-hari, tetapi juga dalam film, seperti film The Raid dan The Raid 2: Berandal karya Gareth Evans.

The Raid dan The Raid 2: Berandal merupakan film action Indonesia yang rilis pada tahun 2011 dan 2014. Dalam kedua film tersebut, banyak ditemukan fenomena ketidaksantunan berbahasa, seperti penggunaan sumpah serapah dan kata-kata kasar. Selain itu, tuturan-tuturan yang mengejek, merendahkan, mencela, dan mengabaikan orang lain juga banyak dituturkan oleh tokohtokohnya. Fenomena ketidaksantunan semacam itu dapat dijelaskan dengan teori ketidaksantunan yang dirumuskan oleh beberapa ahli.

Tuturan tidak santun memiliki strategi yang diterapkan oleh penutur, yakni strategi ketidaksantunan. Selain strategi ketidaksantunan, terdapat pula respons terhadap ketidaksantunan yang diberikan oleh mitra tutur ketika merasakan serangan muka dari penutur. Berikut contoh penggunaan respons terhadap ketidaksantunan dalam film The Raid.

(1) Konteks: Peristiwa tutur terjadi pada saat Andi, Mad Dog, dan Tama berkumpul di markas mereka. Peristiwa tutur yang berlangsung melibatkan Mad Dog (MD) sebagai penutur dan Andi (A) sebagai mitra tuturnya. Dalam peristiwa tutur tersebut, Andi baru saja tiba di markas mereka setelah mengetahui kabar bahwa apartemen Tama diserang. Andi langsung menyalahkan Mad Dog atas penyerangan yang terjadi, namun Mad Dog tidak merespons Andi.

A : “(Kepada Mad Dog) Kerjaan apa lagi yang lu buat, hah?!”

MD : (Tidak merespons, hanya menatap Andi)

$\mathrm{T} \quad$ : "Sini lu! Lihat itu"

A : "(Melihat monitor, berbicara kepada Mad Dog) Lu gila ya?"

MD : "Ngomong apa lu? Ini urusan gua. Gua yang urus"

A : "Lu pake otak lu! Kalo bekingan datang gimana, hah? Lu nggak bisa nembak polisi. Polisi lu bayar, kelar!"

MD : "Emang lu pikir mereka kemari buat minta duit?"

$\mathrm{T}$ : "Nggak akan ada bantuan. Nggak ada bukti apa-apa. Nggak ada bedanya dengan usaha take over yang sudahsudah. Pokoknya nggak ada cerita. Kita libas mereka semua"

A : "Yakin?"

$\mathrm{T} \quad$ : "Gue udah tahu siapa dalangnya. Bangsat tua ini. Berani betul dia masuk di kerajaan gua" 
Pada percakapan (1) di atas, konteks yang bercetak tebal yakni (Tidak merespons, hanya menatap Andi) merupakan respons terhadap ketidaksantunan berupa tidak merespons. Pada percakapan di atas, Andi menyalahkan Mad Dog atas penyerangan yang terjadi di apartemen Tama. Sikap menyalahkan Andi tersebut tertuang dalam tuturannya, yaitu Kerjaan apa lagi yang lu buat, hah?!. Mad Dog memilih untuk tidak merespons perkataan tersebut, meskipun sebenarnya perkataan itu menyerang muka Mad Dog.

Penelitian mengenai ketidaksantunan mulai banyak dilakukan. Beberapa penelitian tersebut adalah (1) penelitian Wijayanto (2014) yang berjudul "Ketidaksantunan Berbahasa: Penggunaan Bahasa Kekerasan di Sinetron Bertema Kehidupan Remaja"; (2) penelitian Rahardi (2014) yang berjudul "Kata Fatis Penanda Ketidaksantunan Pragmatik dalam Ranah Keluarga"; (3) penelitian Saputro (2015) yang berjudul "Ketidaksantunan Berbahasa pada Film Crazy Love Karya Guntur Soeharjanto"; (4) penelitian Gunawan (2017) yang berjudul "Sherlock Holmes' Impoliteness Strategies and Other Characters' Responses in Sherlock TV Series Season 1 Episode 1"; (5) penelitian Hanif (2018) yang berjudul "Ketidaksantunan Tuturan Juri dalam Acara Master Chef di RCTI (Sebuah Pendekatan Pragmatik)"; (6) penelitian Kharisma (2018) yang berjudul "Ketidaksantunan Praktisi Hukum terhadap Saksi Ahli dalam Sidang Jessica Kumala Wongso"; dan (7) penelitian Utami (2019) yang berjudul "Strategi dan Fungsi Ketidaksantunan dalam Reality Show 86 di NET TV". Penelitian ini memiliki beberapa kesamaan dengan penelitian-penelitian di atas, yaitu samasama meneliti tentang ketidaksantunan. Selain itu, penelitian ini juga memiliki perbedaan dengan penelitian-penelitian sebelumnya, yakni pada sumber data dan tujuan penelitian. Penelitian ini ditekankan pada respons terhadap ketidaksantunan yang terdapat dalam film The Raid dan The Raid 2: Berandal. Sejauh penelusuran yang telah dilakukan, belum ditemukan adanya penelitian mengenai respons terhadap ketidaksantunan yang bersumber dari film, terutama film action. Oleh sebab itu, penelitian ini layak untuk dilakukan.

Penelitian ini bertujuan untuk mendeskripsikan penggunaan respons terhadap ketidaksantunan yang digunakan oleh tokoh-tokoh dalam film The Raid dan The Raid 2: Berandal. Penelitian ini diharapkan dapat menambah ilmu pengetahuan, terutama dalam bidang ketidaksantunan bahasa. Melalui penelitian ini, pembaca diharapkan dapat lebih memahami tentang respons terhadap ketidaksantunan yang bisa digunakan untuk merespons ketidaksantunan yang dirasakan dari orang lain.

Teori ketidaksantunan pertama kali dicetuskan oleh Jonathan Culpeper (1996). Dalam perkembangannya, Culpeper (dalam Bousfield dan Locher, 2008: 36) memaparkan ketidaksantunan sebagai "...involves communicative behaviour intending to cause the 'face-loss' of a target or perceived by target to be so." Ketidaksantunan melibatkan perilaku komunikatif yang dimaksudkan untuk 
menyebabkan 'kehilangan muka' dari suatu target atau dirasakan oleh target menjadi demikian. Menurt Rahardi dkk (2018: 91), Culpeper menitikberatkan pada konsep 'face loss' yang berarti kehilangan muka. Perilaku komunikatif yang dilakukan dengan sengaja untuk membuat orang kehilangan muka itu disebut ketidaksantunan. Lebih jauh, Culpeper (1996: 354-355) memaparkan tiga faktor yang melatarbelakangi penggunaan ketidaksantunan berbahasa, yaitu (1) hubungan sosial penutur dan mitra tutur yang sangat akrab atau intim; (2) ketidakseimbangan power atau kekuatan sosial antar penutur; dan (3) keinginan penutur yang sengaja tidak ingin menjaga muka mitra tutur yang mungkin dikarenakan adanya konflik kepentingan.

Adapun Bousfield (2008: 132) menerangkan ketidaksantunan sebagai "...the issuing of intentionally gratuitous and conflictive face-threatening acts (FTAs) that are purposefully performed." Ketidaksantunan dipandang sebagai pencanangan dari tindak pengancaman muka (FTA) yang dilakukan secara sembrono dan konfliktif yang sengaja dilakukan. Definisi tersebut memberi pemahaman bahwa ketika seseorang menyampaikan sebuah tuturan yang dilakukan secara sembrono dan tuturan tersebut dilakukan dengan sengaja hingga menimbulkan konflik atau pertengkaran, maka tuturan tersebut tergolong dalam ketidaksantunan. Rahardi dkk (2018: 91) menjelaskan bahwa Bousfield memberi penekanan pada kata gratuitous (kesembronoan) dan conflicitive (konfliktif) untuk menjelaskan bahasa yang tidak santun tersebut.

Dalam ketidaksantunan, strategi yang dapat diterapkan oleh penutur ada lima, yaitu strategi ketidaksantunan secara langsung, strategi ketidaksantunan positif, strategi ketidaksantunan negatif, strategi kesantunan semu atau sarkasme, dan menahan kesantunan. Ketika merasakan tindak ancaman muka, mitra tutur dapat memilih untuk respons ketidaksantunan atau tidak merespons. Ketika memilih untuk merespons ketidaksantunan, mitra tutur dapat memilih untuk merespons dengan melawan ketidaksantunan atau menerimanya. Untuk melawan ketidaksantunan tersebut, mitra tutur dapat menerapkan dua strategi, yaitu strategi ofensif-ofensif atau strategi ofensif-defensif. Untuk lebih jelasnya, ringkasan pilihan respons terhadap ketidaksantunan dapat dilihat dalam gambar di bawah ini.

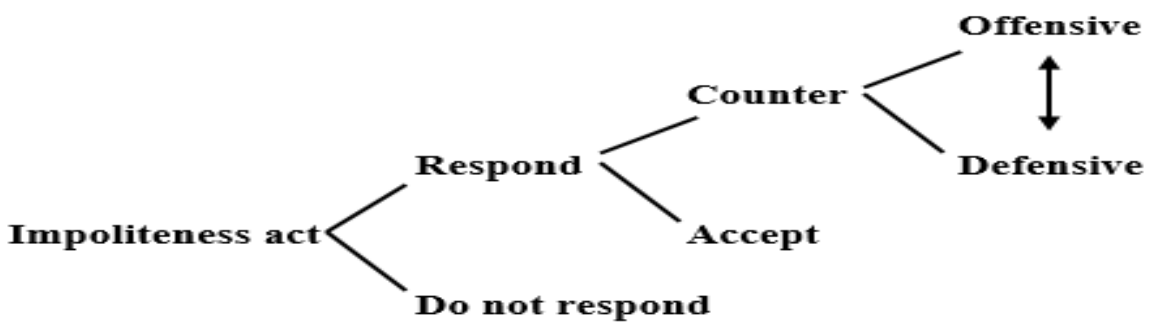

Gambar 1 Ringkasan Pilihan Respons terhadap Ketidaksantunan Sumber: Culpeper, 2003: 1563 


\section{METODE PENELITIAN}

Jenis penelitian yang dilakukan adalah penelitian kualitatif dengan bentuk deskriptif. Sebagaimana yang dikatakan Bogdan dan Taylor (dalam Moleong, 2009: 4), penelitian ini merupakan penelitian kualitatif karena "prosedur penelitian yang menghasilkan data deskriptif berupa kata-kata tertulis atau lisan dari orang-orang dan perilaku yang dapat diamati." Selain itu, penelitian ini bertujuan untuk memaparkan penggunaan bahasa yang terdapat dalam film The Raid dan The Raid 2: Berandal. Adapun bentuk penelitian deskriptif menurut Djajasudarma (2010: 9) merupakan penelitian yang menggambarkan atau mendeskripsikan hasil dari kasus atau fenomena yang diteliti secara sistematis, faktual, dan akurat mengenai data, sifat-sifat serta hubungan fenomena-fenomena yang diteliti.

Data dalam penelitian ini berupa tuturan yang mengandung strategi dan respons terhadap ketidaksantunan dalam film The Raid dan The Raid 2: Berandal. Sumber data diunduh dari Youtube, yakni pada channel Radhi Smarties, dan website https://enx265.com/tag/enx265-movies/. Metode pengumpulan data yang digunakan dalam penelitian ini adalah metode simak dengan teknik unduh dan teknik catat. Setelah dikumpulkan dan diklasifikasikan, data yang ditemukan akan dianalisis dengan metode analisis kontekstual. Rahardi (2009: 36) memaparkan bahwa metode analisis kontekstual adalah cara analisis yang diterapkan pada data dengan mendasarkan dan mengaitkan konteks yang ada dalam sebuah pertuturan.

\section{ANALISIS DAN PEMBAHASAN}

Ketika seseorang merasakan ketidaksantunan, orang tersebut dapat memilih untuk merespons atau tidak merespons ketidaksantunan yang dirasakannya. Apabila orang tersebut memilih untuk merespon, ia dapat merespons dengan melawan atau menerima ketidaksantunan tersebut. Untuk melawan ketidaksantunan yang dirasakan, penutur dapat menggunakan strategi ofensif-ofensif atau strategi ofensif-defensif. Untuk lebih jelasnya, respons terhadap ketidaksantunan dalam film The Raid dan The Raid 2: Berandal akan diuraikan di bawah ini.

\section{Respons Melawan: Strategi Ofensif-Ofensif}

Pada respons ini, penutur memilih untuk melawan ketidaksantunan yang dirasakannya dengan menyerang balik muka mitra tutur. Penggunaan respons ofensif-ofensif dapat dilihat dalam penggalan percakapan berikut.

(2)Konteks: Peristiwa tutur terjadi pada saat Uco dan Yuda sedang berapa di tempat karaoke bersama Joanna dan Karaoke Girl. Peristiwa tutur yang berlangsung melibatkan Joanna (JN) sebagai penutur dan Uco (U) sebagai mitra tuturnya. Dalam peristiwa tutur tersebut, Uco menghina 
Joanna dan Karaoke Girl. Joanna yang tidak terima pun menyerang balik muka mitra tutur.

KG : "Mau cobain minum nggak mas?"

R : "Nggak, makasih"

$\mathrm{U}$ : "Ayo Yud, minum lah. (Menyuruh Karaoke Girl menuangkan minuman untuk Yuda) Ayo tuangin"

$\mathrm{R} \quad$ : "Sorry Co, gue cukup"

U : "Ya kalo nggak minum, nyanyi kek, grepe-grepe cewek sini kek, tapi jangan diem aja dong"

$\mathrm{R} \quad$ : "Ga apa-apa gue nonton aja"

U : "Ya elah, minum kagak, nyanyi kagak. Ngomong dari tadi dong, tahu gini mah langsung aja ke tempat stripties, bisa dapet memek susu pegang oke. Daripada di sini, ama pecun-pecun murahan doang"

JN : "Hei, lo siapa katain kita pecun?"

$\mathrm{U} \quad$ : "Yang pasti sih gue lebih penting daripada lo dan harusnya lo juga udah tahu"

JN : "Bacot lu!"

KG : "Joanna, udah jangan"

U : "Nggak apa-apa"

$\mathrm{U} \quad$ : "Joanna, gue orang yang udah sepantasnya bikin lo takut. Lihat aja temen lo"

JN : “Oh, ya?! Emangnya lo siapa?”

U : "Gini yah, tempat lo kerja, tempat lo tinggal, tempat lo ngewe sama klien, semuanya punya bokap gue. Dan tugas gue untuk mastiin bahwa semua orang kerja di kota ini nunjukkin rasa hormat mereka ke dia"

JN : "Jadi lo preman pasar?"

$\mathrm{R} \quad$ : "Aduh, sini sini deh, gue nyanyi"

U : "Jangan. Biarin aja, dia udah gede gini. Terserah dia dong mau ngomong apa"

JN : "Betul (Mengambil alkohol dan minum)"

U : "Minum aja terus. Biar ga berasa sakitnya"

JN : "Maksud lo apaan?"

$\mathrm{U} \quad$ : "Maksud gue, sekarang giliran lo nyanyi"

JN : "Gue ga mau bernyanyi, gue cuma mau tahu tadi lo ngomong apa"

U : “Udah buran nyanyi! Gue bosen dengerin lo bacot! Yaitu lo! Ayo nyanyi! Gue bayar lo untuk nyanyi atau ngewe. Lo mau yang mana? Ayo pilih! Mau nyanyi? Oke, ayo kita 
pilih lagu. Mau gue pilihin lagunya? Mana daftar lagunya? Ya udah, jangan lama dong ambil daftar lagunya! (Mencegah Karaoke Girl untuk menekan bell) Hei! Jangan sentuh itu! Awas lo!"

KG : (Menekan bell)

$\mathrm{U} \quad$ : "(Menendang Karaoke Girl) Ini dia yang bikin negara ini jadi ancur. Awalnya janji manis. Ya ya ya bisa kok, bisa, bisa, bisa! Tapi kalau udah saatnya untuk ngebuktiin bacotannya itu, 'nggak, nggak, maaf, nggak bisa' Taik! Nggak ada ceritanya malam ini! (Memerintah Joanna) Sekarang, nyanyi!"

JN : (Menyanyi) £ Somewhere `

(Satpam datang ke ruangan mereka)

SP : "Maaf ini, baik saja, Pak?"

U : "Nggak. Nggak apa-apa pak. Nggak apa-apa, kan? Tuh lihat sendiri kan, nggak apa-apa"

JN : "Tolong lepasin!"

U : "Bapak tolong keluar lagi yah, makasih"

JN : "Lepas..."

R : "Biar mereka keluar. Co..."

U : "Keluar!"

(Joanna dan Karaoke Girl segera keluar dari ruangan)

SP : "Malam ini gratis aja, Pak. Terima kasih"

R : “Lo nggak apa-apa?"

U : “Ga apa-apalah, pecun doang emang gue pikirin. Tapi gila aja gila berani ngebacot sama gue, siapa dia gitu! Gue lebih dari yang dia bilang. Lebih dari semua ini. Udah saatnya gue naik, dan gue pengennya bokap sadar"

$\mathrm{R} \quad$ : "Pasti nggak lama lagi"

U : “Oh, ya? Kapan? (Telepon berdering) Tunggu di sini"

U : "Halo?"

Pada percakapan (2) di atas, respons ofensif-ofensif yang ditemukan melibatkan Joanna (JN) dan Uco (U). Joanna (JN) bertindak sebagai penutur dan Uco (U) sebagai mitra tuturnya. Respons ofensif-ofensif yang terdapat dalam data ditunjukkan oleh tuturan yang bercetak tebal, yaitu (i) Hei, lo siapa katain kita pecun?, (ii) Bacot lu!, (iii) Oh, ya?! Emangnya lo siapa?, dan (iv) Jadi lo preman pasar?. Pada percakapan tersebut, Joanna melawan ketidaksantunan yang dirasakannya dengan menyerang balik muka mitra tutur. 
Uco menyerang muka Joanna dengan mengatakan bahwa Joanna adalah pecun. Tuturan Uco tersebut termasuk dalam ketidaksantunan negatif berupa merendahkan orang lain. Joanna tidak terima dengan ucapan Uco tersebut sehingga ia memutuskan untuk melawan ketidaksantunan yang dirasakannya. Joanna menyerang balik muka mitra tutur dengan strategi ketidaksantunan secara langsung, strategi ketidaksantunan positif berupa menggunakan bahasa yang kasar, dan strategi ketidaksantunan negatif berupa mengejek. Pada tuturan Hei, lo siapa katain kita pecun? dan Oh, ya?! Emangnya lo siapa?, Joanna secara langsung dan terus terang menyerang muka mitra tutur dengan mengatakan bahwa Uco tidak pantas menjulukinya pecun. Bagi Joanna, Uco bukanlah siapa-siapa. Uco tidak berhak untuk menghina dan merendahkan Joanna, terlebih di depan umum. Joanna juga menggunakan strategi ketidaksantunan positif berupa menggunakan bahasa yang kasar kepada Uco, yaitu pada tuturan Bacot lu!. Tuturan tersebut diujarkan karena Joanna merasa Uco hanya membual dan banyak omong. Joanna ingin agar Uco diam dan tidak membual dengannya. Selain itu, Joanna juga menyerang muka mitra tutur dengan menggunakan strategi ketidaksantunan negatif berupa mengejek. Pada tuturan Jadi lo preman pasar?, Joanna mengejek Uco dengan mengatakan bahwa Uco hanyalah preman pasar baginya. Joanna juga menuturkan tuturan tersebut dengan seringai di wajahnya, menandakan bahwa ia mengejek dan menghina balik Uco.

\section{Respons Melawan: Strategi Ofensif-Defensif}

Pada respons ini, penutur memilih untuk melawan ketidaksantunan yang dirasakannya dengan mempertahankan mukanya sendiri. Penggunaan respons ofensif-defensif dapat dilihat dalam penggalan percakapan berikut.

(3) Konteks: Peristiwa tutur terjadi pada saat Bowo mencegat Gofar di pintu masuk apartemen Tama. Peristiwa tutur yang berlangsung melibatkan Gofar $(\mathrm{G})$ sebagai penutur dan Bowo (B) sebagai mitra tuturnya. Dalam peristiwa tutur tersebut, Bowo mencegat Gofar secara tiba-tiba dan tidak mengizinkannya pergi. Bowo juga menunjukkan ketidakpeduliannya kepada Gofar yang harus segera naik. Gofar melawan ketidaksantunan yang dirasakannya dengan mempertahankan mukanya sendiri.

B : "Diam! Jangan bergerak!"

G : "Apa-apaan nih? Saya harus ke atas"

B : "Kamu ke laut pun saya juga tidak peduli!"

G : "Istri saya sendirian di atas. Dia udah nunggu obat ini. Jadi saya harus ke atas" 
B : “Udah! Sekali lagi Anda melangkah, itu adalah langkah terakhir Anda!"

R : (Menghalangi Bowo)

B : “Apa-apaan ni?!”

R : "Udahlah"

SJ : "Bowo, cukup!"

B : “(Kepada Rama) Mau jadi jagoan?! Silakan. Jangan dekatdekat!"

$\mathrm{R}$ : "Kamar Bapak nomor berapa?"

G : “726”

R : “Tenang. Nanti saya antar ke kamar. Tapi Bapak tetap harus tenang, sampai area ini aman"

G : “Terus, bagaimana dengan istri saya di atas?”

$\mathrm{R}$ : "Saya ngerti, tapi Bapak tetap harus tenang"

G : “Omong kosong!"

R : "Dengar! Pilihannya hanya dua. Sama saya, atau dia"

SJ : "Oke, semuanya! Kita masuk sekarang! Lu awasin dan tempel dia terus!"

Pada percakapan (3) di atas, respons ofensif-defensif yang ditemukan melibatkan Gofar (G) dan Bowo (B). Gofar (G) bertindak sebagai penutur dan Bowo (B) sebagai mitra tuturnya. Respons ofensif-defensif yang terdapat dalam data ditunjukkan oleh tuturan yang bercetak tebal, yaitu Istri saya sendirian di atas. Dia udah nunggu obat ini. Jadi saya harus ke atas. Pada percakapan tersebut, Gofar melawan ketidaksantunan yang dirasakannya dengan mempertahankan mukanya sendiri.

Pada percakapan di atas, Bowo mencegat Gofar secara tiba-tiba di pintu masuk apartemen Tama dan tidak mengizinkannya untuk naik. Gofar tidak terima dengan sikap Bowo dan menjelaskan alasan mengapa ia harus segera naik ke atas. Penjelasan yang diberikan Gofar tersebut adalah bentuk perlawanan dengan mempertahankan mukanya sendiri. Gofar melawan ketidaksantunan yang dirasakannya tanpa menggunakan tuturan yang tidak santun kepada mitra tutur.

\section{Respons Menerima}

Pada respons ini, penutur memilih untuk menerima ketidaksantunan yang dirasakannya, tetapi penutur tidak melakukan serangan balik kepada mitra tuturnya. Penggunaan respons menerima dapat dilihat dalam penggalan percakapan berikut.

(4)Konteks: Peristiwa tutur terjadi pada saat Yuda bertemu dengan Bangun. Peristiwa tutur yang berlangsung melibatkan 
Yuda (R) sebagai penutur dan Bangun (BG) sebagai mitra tuturnya. Dalam peristiwa tutur tersebut, Uco membawa Yuda yang baru keluar dari penjara menemui Bangun. Di sana, Bangun menyuruh Yuda membuka seluruh pakaiannya. Yuda hanya diam menerima ketidaksantunan yang dilakukan Bangun kepadanya.

GT : "Ini mungkin bukan masalah. Aku hanya ingin memberitahumu saja. Sementara, salah satu dari kita masih bisa mengurs situasi seperti dia"

BG : "Aku akan menyuruh anak buahku untuk memantau situasi. Jika dia kelewat batas, kami akan mengurusnya. Anda tidak perlu khawatir"

GT : "Siapa bilang saya khawatir, njing?"

BG : "Heh. Makasih"

GT : "Harusnya, terima kasih (Goto bersiap untuk pergi)"

BG : "Ah, Goto-san (Bersalaman dengan Goto) (Uco dan Yuda masuk ke ruangan) Ah, itu mereka"

U : "(Menyapa) Pak Goto"

GT : (Hanya mengangguk sebagai respons dan pergi dari kantor Bangun)

BG : "(Menyapa Yuda) Ah, akhirnya ketemu juga di sini"

$\mathrm{R}$ : "Senang ketemu bapak. Uco selalu berbicara banyak mengenai bapak"

BG : “Ah, ya udah seharusnya begitu. Sebetulnya kita pengen sekali kamu bisa keluar lebih cepat. Tapi kamu salah pukul waktu itu. Jadi bapaknya itu anak mempersulit kamu di sana"

R : "Nggak apa-apa"

BG : "Oke. Sekarang buka bajunya"

R : "Maaf?"

BG : "Kamu denger saya, kan?"

U : "Nggak apa-apa Yud, ikutin aja"

$\mathrm{R} \quad$ : "Co, gue nggak mungkin, lo kan tahu gue..."

BG : "Shh. Heh. Saya bukannya nggak percaya sama kamu. Tapi saya nggak percaya sama siapa-siapa. Kalau masalah kamu cuman malu untuk buka baju di depan orang tua seperti saya artinya saya masih baik. Buka"

$\mathrm{R}$ : (Membuka baju dan celananya hingga menyisakan celana dalam saja)

BG : "Semuanya"

$\mathrm{R}$ : (Melepas semua yang ada di tubuhnya) 


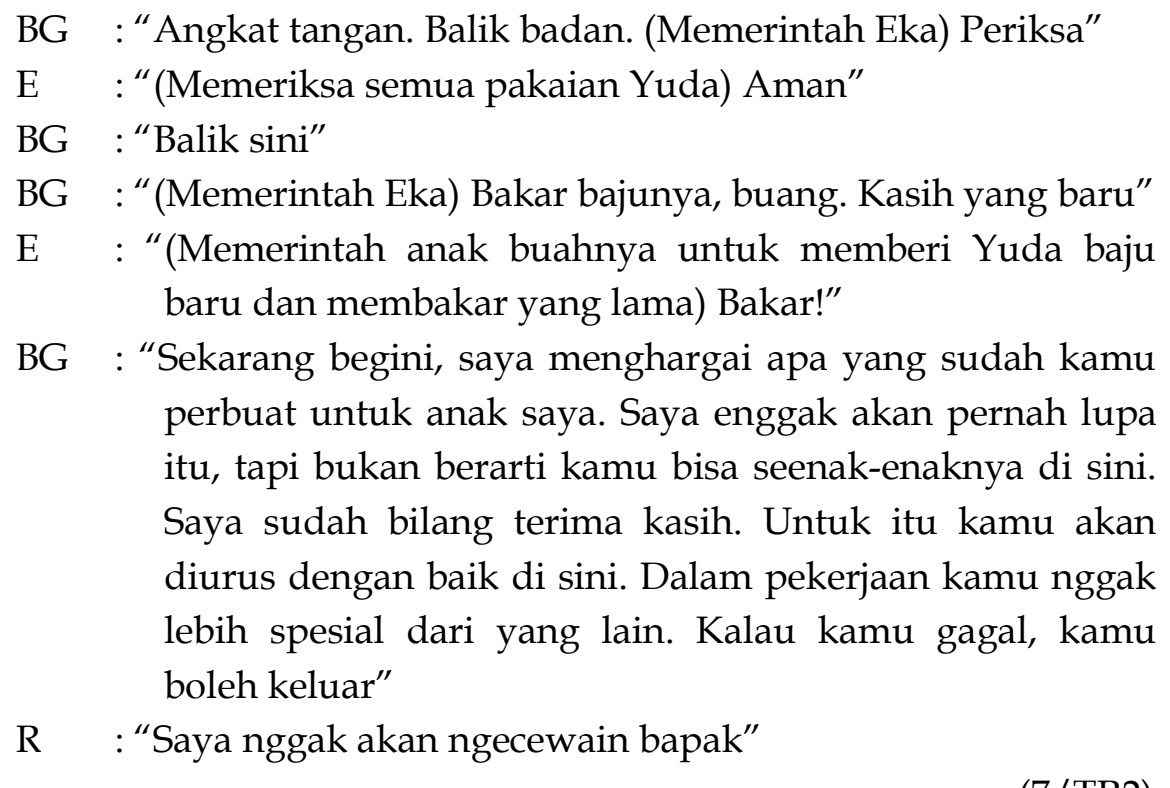

Pada percakapan (4) di atas, respons menerima yang ditemukan melibatkan Yuda (R) dan Bangun (BG). Yuda (R) bertindak sebagai penutur dan Bangun (BG) sebagai mitra tuturnya. Respons menerima yang terdapat dalam data ditunjukkan dengan konteks yang bercetak tebal, yaitu (Melepas baju dan celananya hingga menyisakan celana dalam saja). Pada percakapan tersebut, Yuda (R) menerima ketidaksantunan yang dilakukan Bangun dan menuruti perkataannya.

Pada peristiwa tutur di atas, Yuda memilih untuk menerima ketidaksantunan yang dilakukan Bangun dan tidak menyerang balik muka mitra tutur. Pada konteks yang bercetak tebal, Yuda melakukan apa yang diperintahkan Bangun, meskipun perintah tersebut tidak santun dan mengabaikan pendapat atau keinginan Yuda. Ia juga tidak menyerang balik muka mitra tutur dan hanya diam menerima ketidaksantunan tersebut sambil melakukan apa yang diperintahkan kepadanya.

Penggunaan respons menerima yang lain dapat dilihat dalam penggalan percakapan berikut.

(5) Konteks: Peristiwa tutur terjadi pada saat Uco menemui Bangun di kantornya. Peristiwa tutur yang berlangsung melibatkan Uco (U) sebagai penutur dan Bangun (BG) sebagai mitra tuturnya. Dalam peristiwa tutur tersebut, Uco mencoba membujuk Bangun agar mau memberinya kekuasaan lebih, tetapi Bangun mengabaikan pendapat Uco dan memotong pembicaraannya. Uco menerima ketidaksantunan tersebut dan pergi meninggalkan ruangan. 
E : “Kerjanya bagus bos. Yuda doang kelar semuanya. Dia udah biasa nyikat orang. Nggak ada yang kurang"

BG : "Oke"

BG : "Uco, kasih dia. Kamu kerjanya bagus hari ini. Mereka memang pantas dikasih pelajaran seperti itu. Benar! Dipertahankan, ya"

U : "Makasih, Pah"

BG : "Oke"

U : "Pah?"

BG : "Iya?"

$\mathrm{U}$ : "Saya sempet mikir, melihat keadaan belakangan ini, mungkin udah saatnya saya terima tanggung jawab yang lebih besar, mungkin pegang klien kita yang lebih..."

BG : “Tunggu, saya yang tahu kapan waktunya, tapi nggak sekarang. Belum. Oke? Ada lagi?"

U : "Nggak"

BG : “Oke, makasih, Uco (Memberi Uco kode untuk segera pergi)”

$\mathrm{U}$ : "Makasih (Pergi meninggalkan ruangan)"

Pada percakapan (5) di atas, respons menerima yang ditemukan melibatkan Uco (U) dan Bangun (BG). Uco (U) bertindak sebagai penutur dan Bangun (BG) sebagai mitra tuturnya. Respons menerima yang terdapat dalam data ditunjukkan oleh tuturan yang bercetak tebal, yaitu Enggak. Pada percakapan tersebut, Uco (U) menerima ketidaksantunan yang dirasakannya dari Bangun.

Pada peristiwa tutur di atas, Uco memilih untuk menerima ketidaksantunan yang dilakukan Bangun dan tidak menyerang balik muka mitra tutur. Pada percakapan tersebut, Uco mencoba membujuk Bangun agar mau memberinya kekuasaan lebih, tetapi Bangun mengabaikan pendapat Uco dan memotong pembicaraannya. Ketika Bangun bertanya apakah masih ada yang ingin disampaikan, Uco menjawab dengan Nggak. Respons tersebut menunjukkan bahwa Uco menerima ketidaksantunan Bangun dan tidak berniat melawannya, bahkan ketika Bangun memberinya kode untuk meninggalkan ruangan, Uco menurut dan pergi dari kantor Bangun.

\section{Tidak Merespons}

Pada respons ini, penutur memilih untuk tidak merespons ketidaksantunan yang dirasakannya dari mitra tutur. Penggunaan tidak merespons dapat dilihat dalam penggalan percakapan berikut ini.

(6)Konteks: Peristiwa tutur terjadi pada saat Bejo, Reza, dan Uco sedang makan malam bersama. Peristiwa tutur yang 
berlangsung melibatkan Uco (U) sebagai penutur dan Reza (RZ) sebagai mitra tuturnya. Dalam peristiwa tutur tersebut, Bejo dan Reza sedang berdiskusi perihal kerja sama mereka. Uco kembali dari toilet dan hanya duduk diam mendengarkan pembicaraan mereka. Di tengahtengah percakapan, Reza menyapa Uco dengan julukan yang bersifat menghina. Uco hanya diam dan tidak merespons ketidaksantunan tersebut.

RZ : "Ya pasti bisa dong. Apa aja yang kita mau, kita yang ngatur. Yang penting imbalannya. Muka bar, ya harga baru"

BJ : "Harga baru? Ayolah, Reza"

RZ : "Anggap aja ini harga perkenalan"

BJ : "Goto bayar berapa?"

RZ : "Nggak cerdas pertanyaan lo"

BJ : : "Salahnya di mana?"

RZ : “Di sini gue ketemu lo, bukan dia. Pikir satu angka. Habis makan gue tetep di sini, berarti oke. Hm?"

RZ : "(Menyapa Uco) Woi, jongos. Diem aja lo. Hm?"

$\mathrm{U} \quad$ : (Hanya diam memandang Reza tanpa meresponsnya)

ABBJ : “(Datang menghampiri Bejo yang sedang makan bersama) Bos, bos. Orang itu kabur dari mobil bos"

BJ : : Hubungi semua orang. Siapa yang bisa dapetin dia..."

ABBJ : "Dia sudah di sini bos. Menuju ke atas"

BJ : : "Tahan dia"

ABBJ : "Baik, bos"

RZ : "Semuanya beres?"

BJ : : "(Memerintahkan anak buahnya) Urusin dia"

BJ : " "Reza, tenang aja. Ini semua masih dalam kontrol kita.

Mereka ini orang-orang handal"

BJ : : "(Tongkat Bejo terjatuh) Brengsek!"

Pada percakapan (6) di atas, pilihan tidak merespons yang ditemukan melibatkan Uco (U) dan Reza (RZ). Uco (U) bertindak sebagai penutur dan Reza (RZ) sebagai mitra tuturnya. Pilihan tidak merespons yang terdapat dalam data ditunjukkan dengan konteks yang bercetak tebal, yaitu (Hanya diam memandang Reza tanpa meresponsnya). Pada percakapan tersebut, Uco tidak merespons ketidaksantunan yang dirasakannya dari Reza. 
Pada peristiwa tutur di atas, Uco memilih untuk tidak merespons ketidaksantunan yang dirasakannya dari mitra tutur. Pada percakapan di atas, Reza menyapa Uco yang hanya diam setelah kembali dari toilet. Dalam sapaannya tersebut, Reza menggunakan julukan yang bersifat menghina Uco, yaitu 'jongos' yang berarti pelayan atau pembantu (laki-laki). Uco hanya diam menatap Reza dan tidak berniat melawan ketidaksantunan yang dirasakannya, meskipun tuturan tersebut menyerang muka Uco.

\section{SIMPULAN}

Dalam film The Raid dan The Raid 2: Berandal, banyak ditemukan tuturan yang tidak santun. Ketika merasakan tindak ketidaksantunan, tokoh-tokoh dalam film tersebut memberikan respons kepada penuturnya. Respon terhadap ketidaksantunan yang ditemukan terdiri atas empat respons, yaitu ofensifdefensif sebanyak $51.8 \%$ atau 28 data tuturan, tidak merespons sebanyak $22.2 \%$ atau 12 data tuturan, ofensif-ofensif sebanyak $20.4 \%$ atau 11 data tuturan, dan menerima sebanyak $5.5 \%$ atau 3 data tuturan.

\section{DAFTAR PUSTAKA}

Bousfield, D. (2008). Impoliteness in the Struggle for Power. Dalam Derek Bousfield dan Miriam A. Locher (Eds.), Impoliteness in Language: Studies on its Interplay with Power in Theory and Practice. Mounton de Gruyter.

Culpeper, J. (1996). Towars an Anatomy of Impoliteness. Journal of Pragmatics, 25(3), $349-367$.

Culpeper, J. (2003). Impoliteness Revisited: with Special Reference to Dynamic and Prosodic Aspects. Journal of Pragmatics, 35(10-11), 1545-1579.

Culpeper, J. (2008). Reflections on Impoliteness, Relational Work and Power. Dalam Derek Bousfield dan Miriam A. Locher (Eds.), Impoliteness in Language: Studies on its Interplay with Power in Theory and Practice. Mounton de Gruyter.

Djajasudarma, F. (2010). Metode Linguistik: Ancangan Metode Penelitian dan Kajian. Refika Aditama.

Gunawan, S. (2017). Sherlock Holmes' Impoliteness Strategies and Other Characters' Responses in Sherlock TV Series Season 1 Episode 1. Skripsi. Universitas Sanata Dharma.

Hanif, A. (2018). Ketidaksantunan Tuturan Juri dalam Acara Master Chef Indonesia di RCTI (Sebuah Pendekatan Pragmatik). Skripsi. Universitas Sebelas Maret.

Kharisma, A. (2018). Ketidaksantunan Praktisi Hukum terhadap Saksi Ahli dalam Sidang Jessica Kumala Wongso. Skripsi. Universitas Sebelas Maret.

Moleong, L. J. (2009). Metodologi Penelitian Kualitatif (Edisi Revisi). Remaja Rosdakarya.

Rahardi, R. K. (2009). Sosiopragmatik: Kajian Imperatif dalam Wadah Konteks Sosiokulturan dan Konteks Situasionalnya. Erlangga.

Rahardi, R. K. dkk. (2014). Kata Fatis Penanda Ketidaksantunan Pragmatik dalam Ranah Keluarga. Adabiyyāt: Jurnal Bahasa dan Sastra, 13(2), 149-175. 
Rahardi, R. K. dkk. (2018). Pragmatik: Fenomena Ketidaksantunan Berbahasa. Erlangga.

Saputro, D. K. (2015). Ketidaksantunan Berbahasa pada Film Crazy Love Karya Guntur Soeharjanto. Skripsi. Universitas Sanata Dharma.

Utami, K. L. (2019). Strategi dan Fungsi Ketidaksantunan dalam Reality Show 86 di NET TV. Skripsi. Universitas Sebelas Maret.

Wijayanto, A. (2014). Ketidaksantunan Berbahasa: Penggunaan Bahasa Kekerasan di Sinetron Bertema Kehidupan Remaja. Dalam Markhamah dkk. (Ed.), Ketidaksantunan Berbahasa dan Dampaknya dalam Pembentukan Karakter. Universitas Muhammadiyah Surakarta. 